\title{
PENGEMBANGAN BAHAN AJAR BERBASIS INKUIRI TERINTEGRASI NILAI KARAKTER PEDULI LINGKUNGAN PADA MATERI EKOSISTEM
}

\author{
Agil Lepiyanto \\ Dasrieny Pratiwi \\ Pendidikan Biologi FKIP Universitas Muhammadiyah Metro \\ E-mail: lepi22evo@g mail.com, dasrienyp@yahoo.com
}

\begin{abstract}
This study aimed to obtained material learning based on inquiry integrated character values environmental care. This study uses a model of research is $R n D$. The result of this research show that the quality of material learning based on inquiry integrated character values environmental care is value validation of material expert is $90 \%$, design experts is $86875 \%$ and science teacher at $94.74 \%$. material learning based on inquiry-based integrated character values environmental care should continue to be revised in order to obtain better results.
\end{abstract}

Kata Kunci: Bahan ajar, inku iri, peduli lingkungan

Salah satu permasalahan yang ada di dunia saat ini adalah masalah global warming. Global warming disebabkan terjadinya kerusakan lingkungan. Kerusakan hutan di Indonesia mengalami peningkatan tiap tahun hutan. Jumlah ini tentu saja menunjukkan bahwa menurunnya kesadaran masyarakat terhadap kelestarian lingkungan. Kesadaran masyarakat tentang lingkungan harus dibina sejak dini, salah satu cara pembinaan kesadaran lingkungan adalah melalui pendidikan lingkungan hidup. Fakta di lapangan justru menunjukkan hasil yang berbeda. Hasil pengamatan di beberapa SMP menunjukkan kesadaran siswa terhadap lingkungan juga masih rendah. Salah satu contohnya adalah banyaknya siswa membuang sampah sembarangan. Permasalahan ini tentu saja harus menjadi perhatian. Permasalahan ini bisa diberikan solusi dengan cara mengembangkan bahan ajar berbasis inkuiri terintegrasi nilai karakter peduli lingkungan pada siswa. Salah satu materi pelajaran dalam biologi yang dapat dikembangkan untuk bahan ajar yang dapat mendidik karakter peduli lingkungan adalah materi ekosistem.

Bahan ajar yang dikembangkan nantinya akan berisikan pembelajaran inkuiri. Adanya pembelajaran inkuiri diharapkan siswa dapat belajar secara nyata dan dapat berlatih menyelesaikan masalah terkait dengan materi pelajaran. Pentingnya penerapan pembelajaran inkuiri dilakukan pada mata pelajaran biologi dikemukakan oleh Wena (2010:67) menyatakan bahwa esensi dari model pembelajaran ini adalah mengajarkan siswa memperoleh pengetahuan seperti halnya para peneliti biologi melakukan penelitian. Prosedurnya adalah melibatkan siswa dalam penyelidikan masalah yang sebenarnya (genuine problems) dengan cara melibatkan dalam penelitian, membantu siswa mengidentifikasi konsep atau metode, dan mendorong siswa menemukan cara untuk memecahkan masalah yang dihadapi. Bahan ajar yang akan dikembangkan selain berbasis inkuiri 
juga akan terintegrasi nilai karakter peduli lingkungan. Hasil pengamatan beberapa buku yang digunakan selama masih belum terintegrasi karakter peduli lingkungan.

Kemendiknas (2010) Bahan/buku ajar merupakan komponen pembelajaran yang paling berpengaruh terhadap apa yang sesungguhnya terjadi pada proses pembelajaran. Pemerintah sebenarnya telah menyiapkan program BSE. Buku sekolah eloktronik sebenarnya telah memenuhi memenuhi kelayakan pemakaian berdasarkan penilaian BSNP dari para penulis/penerbit. Walaupun buku-buku tersebut telah memenuhi sejumlah kriteria kelayakan yaitu kelayakan isi, penyajian, bahasa, dan grafika. Bahan-bahan ajar tersebut masih belum secara memadai mengintegrasikan pendidikan karakter di dalamnya. Apabila guru sekedar mengikuti atau melaksanakan pembelajaran dengan berpatokan pada kegiatan-kegiatan pembelajaran pada buku-buku tersebut, pendidikan karakter secara memadai belum berjalan.

Prastowo (2012:17) bahan ajar merupakan segala bahan (baik informasi, alat maupun teks) yang disusun secara sistematis,yang menampilkan sosok utuh dari kompetensi yang akan dikuasai peserta didik dan digunakan dalam proses pembelajaran dengan tujuan perencanaan dan penelaahan implementasi pembelajaran.

\section{METODE}

Model penelitian dan pengembangan ini menggunakan model Research and Develompen $(R \& D)$ yang dikembangkan oleh Sugiyono. Adapun langkah metode research and development ( $\mathrm{R} \& \mathrm{D})$ dapat dilihat pada gambar 1 .

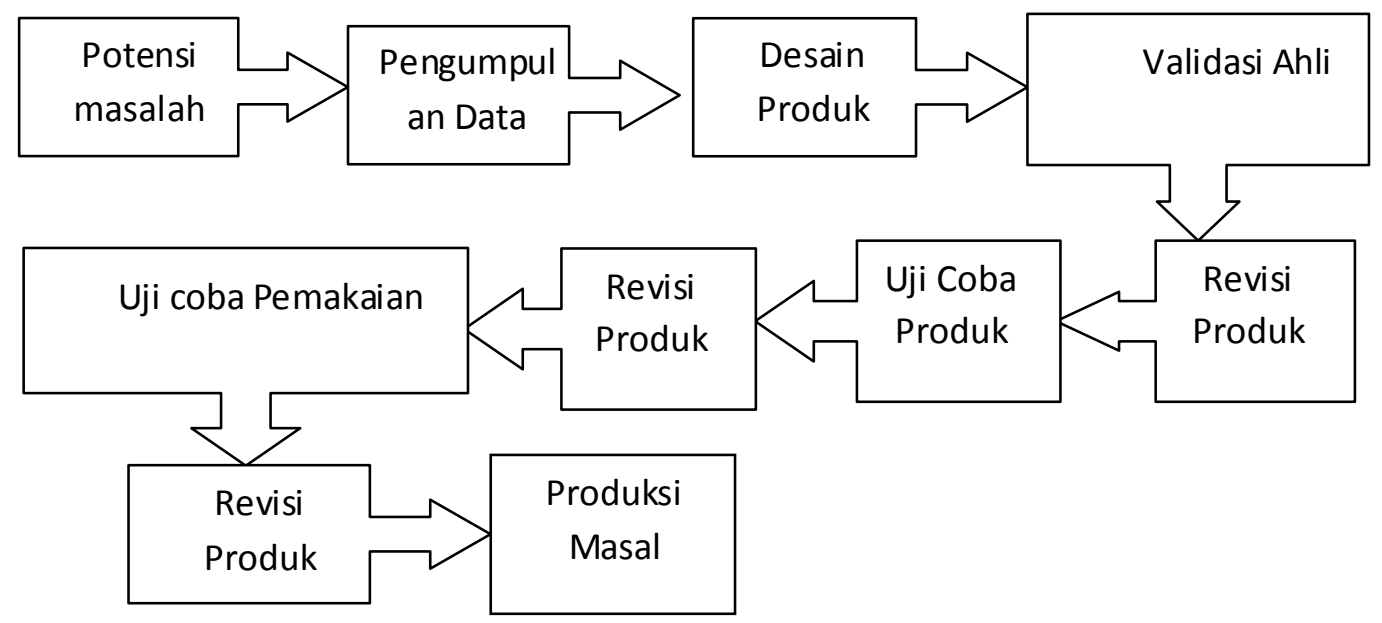

Gambar 1. Modifikasi research and development (R \& D) (Sugiyono:2011) 
HASIL

Tabel 1. Data validasi bahan ajar

\begin{tabular}{|l|l|r|r|}
\hline \multirow{2}{*}{ No } & \multirow{2}{*}{ Ahli } & \multicolumn{2}{|c|}{ Persentase (\%) } \\
\cline { 3 - 4 } & & Tahap 1 & \multicolumn{1}{c|}{ Tahap 2 } \\
\hline 1 & & 74 & 90 \\
& Ahli materi & 74.375 & 86.875 \\
\hline 2 & Desain & & \\
\hline 3 & & 74.74 & 94.74 \\
\hline
\end{tabular}

PEMBAHASAN

Penelitian ini menghasilkan bahan ajar berbasis inkuiri dan terintegrasi nilai karakter peduli lingkungan. Model inkuiri yang dikembangkan merujuk pada langkah Sanjaya (2008:202) langkah pembelajaran inkuiri terdiri atas 1) orientasi, 2) merumuskan masalah, 3) merumuskan hipotesis, 4) mengumpulkan data, 5) menguji hipotesis, 6) merumuskan kesimpulan". Berikut merupakan contoh tahapan inkuiri yang ada dalam bahan ajar pada topik Identifikasi komponen ekosistem

1. Bentuklah kelompok dengan anggota setiap kelompok tidak lebih 5 orang!

2. Masing-masing kelompok, pilihlah suatu ekosistem di lingkungan sekolah, misalnya kebun botani, kebun taman, padang rumput (terbuka dan tertutup/rimbun)!

3. Buatlah terlebih dahulu rumusan masalah yang ingin diselesaikan sesuai dengan topik pada lembar kegiatan siswa 1 !

4. Dari rumusan masalah tersebut buatlah hipotesis/dugaan jawaban sementara!

5. Setiap kelompok membuat plot pengamatan dengan metode kuadrat, dengan kuadrat ukuran 2 $m$ dengan tali rapia pada habitat ekosistem yang telah dipilih masing-masing kelompok!

6. Lakukan pengamatan faktor biotik pada kuadrat tersebut!

7. Catatlah semua organisme (hewan dan tumbuhan) yang ditemukan pada kuadrat tersebut!

8. Ulangi kegiatan tersebut no. 6 s.d 7 minimal 2 kali untuk mendapatkan data yang signifikan dengan cara memindahkan kuadrat kelokasi lain pada ekosistem tersebut!

9. Catat pula faktor abiotik ekosistem tempat pengamatan tersebut (suhu, kelembaban, angin, cahaya)!

10. Buatlah tabel hasil pengamatan!

11. Analisislah data yang telah didapatkan untuk menjawab hipotesis yang telah dibuat!

12. Tuliskan kesimpulan hasil analisis data yang telah dilakukan, sesuaikah dengan hipotesis yang telah kalian buat sebelumnya!

13. Bersihkahlah sampah-sampah serta sisa-sisa kegiatan pengamatan yang telah kalian lakukan!

14. Setelah lingkungan bersih silahkan kerjakan laporan pengamatan dengan format berikut!

Format Jawaban kegiatan Siswa 1
A. Rumusan Masalah
B. Kajian Pustaka
C. Hipotesis
D. Data Hasil Pengamatan 
E. Analisis data dan Pembahasan

F. Kesimpulan

Dari salah satu tahapan yang dikembangkan dalam bahan ajar terlihat bahwa terdapat langkah inkuiri, dan nilai karakter peduli lingkungan, langkah inkuiri terlihat ketika siswa diminta untuk menyusun rumusan masalah, membuat hipotesis, mengumpulkan data hasil pengamatan, membuat analisis dan pembahasan, serta membuat kesimpulan. Nilai karakter yang Nampak dalam bahan ajar salah satuya adalah Bersihkahlah sampah-sampah serta sisa-sisa kegiatan pengamatan yang telah dilakukan pada saat pengamatan.

Produk yang telah dikembangkan kemudian dilakukan uji validasi ahli. Tabel 1 diperoleh bahwa pengembangan bahan ajar berbasis inkuiri terintegrasi nilai karakter peduli lingkungan dilakukan validasi ahli sebanyak 2 kali. Pada tahap 1, Ahli materi $74 \%$, ahli desain $74.375 \%$ dan guru IPA $74,74 \%$. Nilai validasi ahli pada tahap 1 jika dikovnversi pada tahap 1kriteria tingkat kelayakan menurut ahli dan pengguna menurut Riduwan dan Akdon (2007), maka dinyatakan Baik, meskipun dinyatakan baik tetap harus diperbaiki karena bahan ajar memiliki beberpa saran dari para ahli. Hasil validasi tahap 2 didapatkan nilai validasi ahli materi $90 \%$, ahli desain $86.875 \%$ dan guru IPA 94,74\%. Nilai tersebut jika dikonversikan pada Kriteria tingkat kelayakan menurut ahli dan pengguna menurut Riduwan dan Akdon (2007), maka dinyatakan sangat baik. Berikut merupakan beberapa saran dari ahli

Tabel2. Saran ahli tentang bahan ajar

\begin{tabular}{|l|l|}
\hline No & \multicolumn{1}{|c|}{ Saran/Komentar } \\
\hline 1 & $\begin{array}{l}\text { Beberapa konsep masih sulit dipahami } \\
\text { Contohnya ekologi dan simbiosis }\end{array}$ \\
\hline 2 & Terdapat kalimat yang sulit dipahami \\
\hline 3 & $\begin{array}{l}\text { Kesalahan penulisan istilah } \\
\text { Contohnya herbivore, karnivor }\end{array}$ \\
\hline 4 & Gambar karnoivora seharusnya diberi nama hewan \\
\hline 5 & Kata pengantar tidak perlu diberi background \\
\hline 6 & Layout/ tata letak tulisan pada kotak tidak perlu rata tengah \\
\hline 7 & Terdapat beberapa kesalahan pengetikan tulisan \\
\hline 8 & Bahan ajar diberi halaman \\
\hline 9 & Pemberian tanda baca \\
\hline 10 & Urutan penomoran harus benar \\
\hline 11 & $\begin{array}{l}\text { Daftar Isi } \\
\text { Kalimat harus sesuai dengan EYD dan tata tulis yang benar }\end{array}$ \\
\hline
\end{tabular}

\section{KESIMPULAN DAN SARAN Kesimpulan}

Hasil Pengembangan bahan ajar sudah sesuai dengan pembelajaran inkuiri terintegrasi nilai karakter peduli lingkungan, hasil didasarkan penilain oleh nilai validasi ahli materi $90 \%$, ahli desain $86.875 \%$ dan guru IPA 94,74\%. 


\section{Saran}

Bahan ajar bahan ajar sudah sesuai dengan pembelajaran inkuiri terintegrasi nilai karakter peduli lingkungan namun harus terus direvisi agar mendapatkan hasil yang lebih baik

\section{DAFTAR RUJUKAN}

Kemdiknas. 2010. Pendidikan Karakter Di Sekolah Menengah Pertama. Jakarta: Ditjen mandikdasmen.

Prastowo, A. 2012. Panduan Kreatif Membuat Bahan Ajar Inovatif. Yogyakarta: DIVA Press.

Riduwan \& Akdon. 2007. Rumus dan Data dalam Analisis Statistika. Bandung: Alfabeta Sugiyono. 2011. Metode Penelitian Pendidikan Pendekatan Kuantitatif, Kualitatif, dan $R \& D$. Bandung: Alfabeta.

Sanjaya, W. 2008. Strategi Pembelajaran Berorientasi Standar Proses Pendidikan. Jakarta: Kencana Predana Media Group.

Wena, M. 2010. Strategi Pembelajaran Inovatif Kontemporer. Jakarta: Bumi Aksara. 